\title{
Supplementation of organic acid blends in water improves growth, meat yield, dressing parameters and bone development of broilers
}

\author{
ME Hossain $^{1 *}$, F Nargis ${ }^{2}$ \\ ${ }^{1}$ Department of Poultry Science, Bangladesh Agricultural University, Mymensingh; ${ }^{2}$ Institute for Inclusive \\ Finance and Development, Dhaka, Bangladesh
}

\begin{abstract}
The present study was conducted in order to examine the effects of supplementing two liquid organic acid blends on growth performance, meat yield, dressing parameters, organ weights and bone development of broilers. A total of 120 broiler chicks were assigned to five dietary treatments in four replications with six birds per replication over a period of 5 weeks, following a completely randomized design. Dietary groups included; Control $=$ Without organic acids; $A W-C=$ Activate continuous administration; $\mathrm{AW}-\mathrm{P}=$ Activate periodic administration; $\mathrm{N}-\mathrm{C}=$ Nutrilac continuous administration; $\mathrm{N}-\mathrm{P}$ $=$ Nutrilac periodic administration. Results indicated that supplementation of organic acids improved $(P<0.05)$ growth performance of broilers compared to the control. Among the supplemented groups, highest $(\mathrm{P}<0.05)$ body weight and body weight gain were in the AW-C group, followed by the N-C, AW$\mathrm{P}$, and $\mathrm{N}-\mathrm{P}$ groups. Feed intake was higher $(\mathrm{P}<0.05)$ in the AW-C and $\mathrm{N}-\mathrm{C}$ groups compared to the N-P and control groups. Feed conversion ratio was improved $(P<0.05)$ in the organic acid groups, and the AW-C group showed the best value. Dressing yield as well as thigh and drumstick meat relative weights were higher $(P<0.05)$ in the organic acid groups compared to control, whereas breast meat increased $(P<0.05)$ in the AW-C group compared to the AW-P and control groups. Increased $(P<0.05)$ relative weights of head and neck were observed in the AW-C group as well as that of gizzard in the N-C group compared to the other groups. On the other hand, abdominal fat content decreased $(P<0.05)$ in the organic acid groups. Whole leg and wing bone relative weights increased $(P<0.05)$ in the AW-C, AW-P, and $\mathrm{N}-\mathrm{C}$ groups compared to the other groups. Further, longer $(\mathrm{P}<0.05)$ shank in the organic acid groups as well as longer drumstick bone length in the AW-C group were observed compared to the other groups. It was concluded based on the study results that supplementation of both organic acid blends improves growth performance, increases meat yield, organ development, dressing parameters and influences bone development of broilers. Therefore, as continuous addition of Activate showed better results compared to Nutrilac in terms of some tested parameters, it could be applied to broiler water to exert beneficial effects.
\end{abstract}

Key words: Organic acids, Growth performance, Meat yield, Bone development, Broiler

Bangladesh Animal Husbandry Association. All rights reserved.

Bang. J. Anim. Sci. 2016. 45 (1): 7-18

\section{Introduction}

Considering the health hazards associated with antibiotic growth promoters and their addition to poultry diets, it is of great interest to investigate potential alternatives capable of maintaining growth performance and beneficial intestinal microbial populations. Among the candidate replacements for antibiotics are organic acids, both individual acids and blends of several acids (Gunal et al., 2006). Unlike antibiotics, the antimicrobial activity of organic acids is $\mathrm{pH}$ dependent (Ozduven et al., 2009). Probable modes of action of organic acids include reduction of the digesta $\mathrm{pH}$ value in the gastrointestinal tract (Ravindran and Kornegay, 1993), regulation of the microbial population balance in the gut, stimulation of digestive enzyme secretion (Harada et al., 1988; Thaela et al., 1998), and promotion of growth and recovery of the intestinal morphology (Galfi and Bokori, 1990; Walsh et al., 2007). Organic acids have clear and significant benefits in weanling piglets ( $\mathrm{Li}$ et al. 2008) and have been observed to benefit poultry performance (Haque et al., 2010; Chowdhury et al., 2009). Several studies have suggested that

\footnotetext{
*corresponding author: mehossain_bau@yahoo.com
} 
the addition of organic acids to broiler rations improved weight gain (Afsharmanesh and Pourreza, 2005; Haque et al., 2010), increase feed consumption (Moghadam et al., 2006), improve feed efficiency (Abdel-Fattah et al., 2008), and influence immune responses (Rahmani and Speer, 2005; Abdel-Fattah et al., 2008). In addition, organic acid supplementation increases retention of phosphorus (Brenes et al., 2003; Liem et al., 2008), tibia ash (RafaczLivingston et al., 2005; Martinez-Amezcua et al., 2006) and toe ash (Atapattu and Nelligaswatta, 2005) in broiler chicks.

Water quality management is very important for guaranteeing broiler performance. Contaminated drinking water is the most prominent risk factor for the spread of bacterial infection, such as Campylobacter, in broiler flocks (Chaveerach et al., 2004). Therefore, acidified drinking water could play a crucial role in terms of biosecurity in preventing the spread of pathogenic organisms via drinking water among broiler flocks (Kapperud et al., 1993; Pearson et al., 1993; Gibbens et al., 2001). In the broiler industry, different organic acids have been added to drinking water. For example, formic acid, acetic acid, and propionic acid have very high solubilities in water (Freitag, 2007). Desai et al. (2007) indicated that inclusion of a combination of formic acid and propionic acid in drinking water increases weight gain of broilers and improves the feed conversion ratio (FCR). In addition, Samanta et al. (2010) reported that organic acids improve gastric proteolysis as well as the digestibility of proteins and amino acids. Further, organic acids have antimicrobial effects due to their diffusion through the bacterial cell membrane and subsequent dissociation into anions and protons, which disturbs the electron balance inside the cell (Philipsen, 2006). Several studies have also reported that both dietary formic acid and propionic acid reduce the small intestinal, cecal, and fecal populations of Salmonella and E. coli in chickens (Izat et al., 1990; Al-Tarazi and Alshawabkeh, 2003). However, addition of acetic acid to drinking water has no effect on the performance or ileal microbial counts of chickens (Akbari et al., 2004.). In addition, Runho et al. (1997) indicated that dietary addition of fumaric acid does not affect body weight gain of broilers, although it does improve the FCR. Other studies have shown that supplementation of lactic acid or butyric acid to water or feed significantly reduces Salmonella colonization in crops or the intestine (Byrd et al., 2001; Cox et al., 1994). Laboratory trials have proven that formic acid, both individually and in combination with other organic acids, has greater bactericidal effects on $E$. coli and Salmonella (Liem, 2007; Stonerock, 2007). Recent studies (Haque et al., 2010; Chowdhury et al., 2009) reported that supplementation of dietary organic acids such as citric acid enhances growth performance of broiler chicks, increases bone ash deposition, and produces healthy broilers possessing a stronger immune response against enteric pathogens and infectious diseases.

Organic acids have been used for decades to preserve and protect feeds from microbial and fungal destruction or to increase the preservation of fermented feeds (Canibe, 2001; Giesen, 2005; Freitag, 2007). Acidification of drinking water is another implementation method commonly used in the broiler industry, but studies on its efficacy in broilers are limited. Based on previous observations, in our study, we applied two liquid organic acid blends to drinking water of broilers. The objectives were to determine the effects of organic acid supplementation to drinking water on growth performance, meat yield, dressing parameters, internal organ weights, and bone development of broilers.

\section{Materials and Methods}

\section{Experimental designs, birds and diet}

A total of 120 broiler chicks (Cobb 500) were assigned to five dietary treatments in four replications with six birds per replication over a period of 5 weeks, following a completely randomized design. Dietary groups included; Control = Without organic acids; $\mathrm{AW}-\mathrm{C}=$ Activate-continuous: $1 \mathrm{~mL} / 3 \mathrm{~L}$ for one part of the day during the whole period; AW-P = Activateperiodic: $1 \mathrm{~mL} / 3 \mathrm{~L}$ during only the $2^{\text {nd }}$ and $4^{\text {th }}$ weeks; $\mathrm{N}-\mathrm{C}=$ Nutrilac-continuous: $1.5 \mathrm{~mL} / 1 \mathrm{~L}$ for one part of the day during the whole period; N-P $=$ Nutrilac-periodic: $1.5 \mathrm{~mL} / 1 \mathrm{~L}$ during only the $2^{\text {nd }}$ and $4^{\text {th }}$ weeks. Activate \{liquid organic acid blend of Novus International Inc., St. Charles, MO; composed of propionic acid, formic acid, and 2- 


\section{Performances of broilers with organic acid supplementation}

hydroxy-4-methylthio-butanoic acid $\}$ and Nutrilac \{liquid organic acid blend of Novartis (Bangladesh) Limited, Dhaka, Bangladesh; composed of lactic acid and formic acid\} were collected from a local market. The dosage was selected according to the manufacturer's instructions. All birds received a starter diet from 0-3 weeks and a finisher diet from 4-5 weeks. All diets were formulated to meet the nutrient requirements of broiler chickens (NRC, 1994). Composition of ingredients and estimated nutrient contents of diets are shown in Table 1.

\section{Broiler management}

The bird shed and necessary equipments were properly cleaned, washed, dried, disinfected and subsequently left empty for 1 week before the arrival of chicks. Fresh, cool and clean drinking water supplemented with water additive was supplied to experimental birds once every morning during the entire experimental period or during the $2^{\text {nd }}$ and $4^{\text {th }}$ weeks. Fresh, clean and dried rice husk was used as litter material at a depth of about $3 \mathrm{~cm}$. The litter and housing area were disinfected with a safe and suitable disinfectant every other day. Care was taken to ensure proper ventilation as birds advanced in age and they were vaccinated against Gumboro and Newcastle diseases. Brooding temperature was maintained at $32^{\circ} \mathrm{C}$ at the beginning and then reduced gradually at a rate of $2.5^{\circ} \mathrm{C}$ per week until the birds had adjusted to the environmental temperature. Broilers were exposed daily to 23 hours of continuous light followed by a 1 hourdark period throughout the experimental period. Floor space given to each broiler was $960 \mathrm{~cm}^{2}$. Chicks were handled carefully to avoid any pain or injury. Birds were fed ad libitum and had free access to water throughout the whole study.

Table 1. Ingredients and chemical composition of diets

\begin{tabular}{lcc}
\hline Item & Starter (0-3 weeks) & Finisher (4-5weeks) \\
\hline Ingredients (\%, as feed basis) & & 59.44 \\
Yellow corn & 57.37 & 25.40 \\
oybean meal & 26.50 & 4.70 \\
Rice polish & 5.00 & 2.20 \\
Soybean oil & 2.00 & 5.00 \\
Protein concentrate & 5.50 & 0.25 \\
Salt & 0.25 & 1.50 \\
Dicalcium phosphate & 1.64 & 0.88 \\
Limestone & 0.92 & 0.30 \\
Vit-Min. premix ${ }^{1}$ & 0.30 & 0.07 \\
Choline chloride & 0.08 & 0.16 \\
L-lysine & 0.24 & 0.10 \\
Methionine & 0.20 & 100 \\
Total & 100 & 21.00 \\
Calculated chemical composition (\% dry matter) & & 4.50 \\
Crude protein & 22.50 & 6.00 \\
Crude fat & 4.00 & 0.70 \\
Crude fiber & 6.00 & 0.85 \\
Methionine & 0.79 & 0.52 \\
Calcium & 0.90 & 3150 \\
Available phosphorus & 0.54 & 3100 \\
ME (kcal/kg) & & \\
\hline
\end{tabular}

Provided the following nutrients per $\mathrm{kg}$ of diet: vitamin A, 6000IU; vitamin D3, 800IU; vitamin E, 20IU; vitamin K3, 2mg; thiamin, 2mg; riboflavin, 4mg; vitamin B6, 2mg; vitamin B12, 1mg; pantothenic acid, $11 \mathrm{mg}$; niacin, $10 \mathrm{mg}$; biotin, 0.02mg; $\mathrm{Cu}, 21 \mathrm{mg} ; \mathrm{Fe}, 100 \mathrm{mg} ; \mathrm{Zn}$, $60 \mathrm{mg} ; \mathrm{Mn}, 90 \mathrm{mg} ; \mathrm{I}, 1.0 \mathrm{mg} ; \mathrm{Co}, 0.3 \mathrm{mg}$ and Se, $0.3 \mathrm{mg}$. 


\section{Performances of broilers with organic acid supplementation}

\section{Growth performance measurement}

To calculate body weight gain, body weights of broilers were measured every week from the initial day to the final day of the study. Feed intake of broilers was determined by offering a known quantity of feed and then weighing residues on a weekly basis. Feed conversion ratio (FCR) was calculated based on the ratio of the amount of feed consumed to body weight gain of broilers.

\section{Measurement of dressing parameters, meat yield and bone development}

At the end of the experimental period, two broilers with average pen weights from each replication were selected, slaughtered and dissected. Meat of dissected broiler was separated from carcasses following the procedure of Jones (1984). After complete bleeding, heads, legs, feathers, viscera and skin were removed in order to determine carcass weights. Meat (breast, thigh, drumstick and wing) and bone (whole leg, drumstick, thigh and wing) relative weights were determined by calculating the weight of each meat or bone with respect to body weight. Bone length of neck, shank, drumstick, thigh and wing were measured in centimeters $(\mathrm{cm})$. Relative weights of dressing parameters (head, neck, blood, feather, skin and abdominal fat) and internal organ (liver, heart and gizzard) were also determined by calculating the weight of each parameter or organ with respect to body weight.

\section{Statistical analysis}

Data were analyzed by using the general linear models of SAS (2003) to estimate variance components with a completely randomized design. Duncan's multiple comparison tests were used to examine significant differences among the treatment means. The level of significance was set at $\mathrm{P}<0.05$.

\section{Results and Discussion}

\section{Growth performance}

Supplementation of organic acids affected growth performance of broilers. Figure 1 showed that body weight increased $(P<0.05)$ in the AW-C, N-C, and $\mathrm{N}-\mathrm{P}$ groups by the $2^{\text {nd }}$ week compared with the control group. Higher $(P<0.05)$ body weight was observed in the AW-C group by the $3^{\text {rd }}$ week as well as the AW-C and $\mathrm{N}-\mathrm{C}$ groups by the $4^{\text {th }}$ week compared to others. Final body weight was higher in the supplemented groups compared to the control group and the AW-C group showed the highest value $(P<0.05)$. Body weight gain was higher $(P<0.05)$ in the supplemented groups after 2 weeks. Throughout the total experimental period, the AW-C group showed the highest body weight gain compared to the control group, followed by those of the N-C, AW-P, and N-P groups $(P<0.05)$. After 2 weeks, feed intake significantly increased among the treatment groups. Specifically, the AW-C and N-C groups consumed higher $(P<0.05)$ amounts of feed compared to the control and N-P groups throughout the total experimental period. Additionally, the FCR was higher in the supplemented groups by the $4^{\text {th }}$ and $5^{\text {th }}$ weeks as well as throughout the total experimental period compared to the control group and the AW-C group showed the best value $(P<0.05)$.

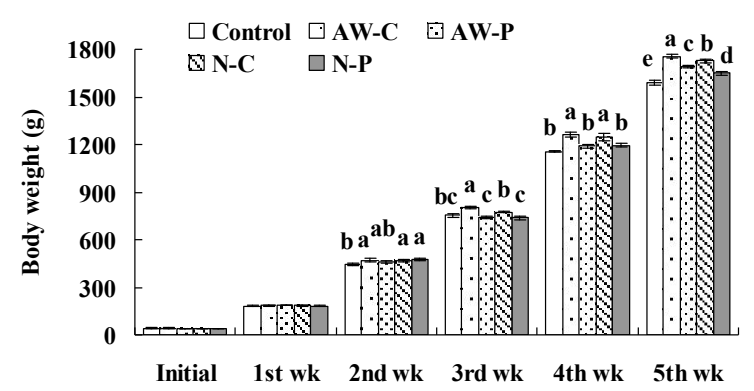

Figure 1. Effects of organic acids on body weight of broilers. Data are presented as the mean \pm SE. Bars within a time class not sharing a common letter are significantly different $(P<0.05)$. Control $=$ Without organic acids; $\mathrm{AW}-\mathrm{C}=$ Activate continuous administration; AW-P $=$ Activate periodic administration; $\mathrm{N}-\mathrm{C}=$ Nutrilac continuous administration; $\mathrm{N}-\mathrm{P}=$ Nutrilac periodic administration

\section{Meat yield}

Meat yields of the different treatment groups are represented in Figure 2. Supplemented groups showed higher $(\mathrm{P}<0.05)$ thigh and drumstick meat yields compared to the control group. Breast meat yield was also higher $(P<0.05)$ in the AW-C group compared to the control and AW-P groups, whereas, wing meat was not significantly $(P>0.05)$ different among the groups.

\section{Dressing parameters}

Data concerning dressing parameters are presented in Table 3. Dressing yield was higher 
$(\mathrm{P}<0.05)$ in the supplemented groups compared to the control group. Head and neck relative weights increased in the organic acid groups and the AW-C group exhibited the highest value $(P<0.05)$. Abdominal fat content decreased in the treated groups, with the $\mathrm{N}-\mathrm{C}$ group showing the lowest value. Heavier gizzard weight was also observed in the $\mathrm{N}-\mathrm{C}$ group $(\mathrm{P}<0.05)$. Other parameters were not affected $(P>0.05)$ among the groups.

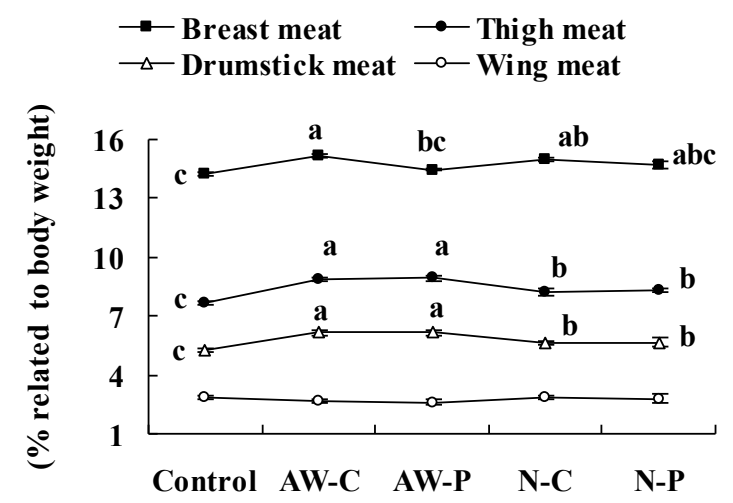

Figure 2. Effects of organic acids on meat yield of broilers (\% related to body weight). Data are presented as the mean \pm SE. Mean values of individual meat yields within treatments not sharing a common letter are significantly different $(P<0.05)$. Control $=$ Without organic acids; AW-C = Activate continuous administration; AW-P = Activate periodic administration; $\mathrm{N}-\mathrm{C}=$ Nutrilac continuous administration; $\mathrm{N}-\mathrm{P}=$ Nutrilac periodic administration.

\section{Bone development}

Bone development results of broilers among the different treatments are shown in Figure 3 and Table 4. Whole leg bone relative weight were higher $(P<0.05)$ in the supplemented groups compared to the control group. Thigh bone relative weight increased $(P<0.05)$ in the $A W-C$, AW-P and $\mathrm{N}-\mathrm{C}$ groups compared to the control group. Shank and drumstick lengths were also higher $(P<0.05)$ in the supplemented group compared to the control group, and the AW-C group showed the longest drumstick bone. Drumstick and wing bone relative weight as well as neck, thigh and wing bone length were not significantly different among the groups $(P>0.05)$.

\section{Discussion}

In poultry production, water should be as clean as possible in order to avoid contamination by microorganisms. High quality water is very important to maintain good digestion and a healthy gut flora, which increase the absorption of all essential nutrients (Sureshkumar, 2011). Therefore, acidified drinking water could play a crucial role in ensuring the biosecurity of broiler flocks.

In this study, organic acid supplementation increased body weight and feed intake of broiler as well as improved the FCR. Improvements in growth performance are frequently attributed to the composition and activity of the gut microflora, which regulate nutrient utilization (Yang et al., 2009). Supplementation of organic acids in drinking water helps to reduce the level of pathogens in water, crops and the proventriculus, regulate the gut microflora, increase feed digestion and improve growth performance of birds (Philipsen, 2006). Desai et al. (2007) demonstrated that inclusion of a combination of formic acid and propionic acid in drinking water increases body weight gain of broiler and improves the FCR, thereby increasing nitrogen retention. Moreover, Samanta et al. (2010) reported that organic acid supplementation improves gastric proteolysis while improving the digestibility of proteins and amino acids in broiler. It has been reported that dietary organic acids such as citric acid increase body weight (Afsharmanesh and Pourers 2005; Abdel-Fattah et al. 2008; Chowdhury et al., 2009), feed consumption (Moghadam et al. 2006; Atapattu and Nelligaswatta, 2005) and feed efficiency (Afsharmanesh and Pourreza 2005; Haque et al., 2010) of broilers. However, other studies reported that supplementation of butyric acid, lactic acid, acetic acid or formic acid to feed or water has no effect on performance of chickens (Cox et al., 1994; Akbari et al., 2004).

Moreover, Garcíaet al., 2007) indicated that dietary supplementation of formic acid has no effect on body weight gain of broilers but improves the FCR. Among different acids and treatment groups, a continuous supply of activate exerted the greatest benefits in this study. Activate is a combination of liquid organic and inorganic acids that includes 2-hydroxy-4methylthio-butanoic acid, a highly available source of methionine (Yi et al., 2007) that has been proven to have a strong, acidification and synergistic effect in water when combined with selected inorganic and organic acids. 


\section{Performances of broilers with organic acid supplementation}

Table 2. Effects of organic acids on growth performance of broilers

\begin{tabular}{lcccccc}
\hline Parameter & \multicolumn{3}{c}{ Treatment } & N-P & PSE \\
\cline { 2 - 7 } & Control & AW-C & AW-P & N-C & & \\
\hline Body weight gain (g/broiler) & & & & 141.61 & 139.98 & 2.65 \\
1st week & 139.53 & 141.89 & 143.63 & 15.97 \\
2nd week & $258.83^{\mathrm{b}}$ & $284.22^{\mathrm{a}}$ & $277.06^{\mathrm{ab}}$ & $285.28^{\mathrm{a}}$ & $291.06^{\mathrm{a}}$ & 15.34 \\
3rd week & $314.11^{\mathrm{ab}}$ & $333.56^{\mathrm{a}}$ & $277.10^{\mathrm{b}}$ & $304.33^{\mathrm{ab}}$ & $263.42^{\mathrm{c}}$ & 21.34 \\
4th week & $401.64^{\mathrm{b}}$ & $461.67^{\mathrm{a}}$ & $449.11^{\mathrm{a}}$ & $474.78^{\mathrm{a}}$ & $457.25^{\mathrm{a}}$ & 27.68 \\
5th week & $430.08^{\mathrm{c}}$ & $493.01^{\mathrm{ab}}$ & $501.02^{\mathrm{a}}$ & $478.22^{\mathrm{ab}}$ & $456.33^{\mathrm{bc}}$ & 25.50 \\
Total (0-5 week) & $1544.2^{\mathrm{e}}$ & $1714.33^{\mathrm{a}}$ & $1647.8^{\mathrm{c}}$ & $1684.35^{\mathrm{b}}$ & $1608.03^{\mathrm{d}}$ & 20.02 \\
Feed intake (g/broiler) & & & & \\
1st week & 235.96 & $234.1^{\mathrm{a}}$ & $233.9^{\mathrm{a}}$ & $232.71^{\mathrm{a}}$ & $231.92^{\mathrm{a}}$ & 5.50 \\
2nd week & $454.42^{\mathrm{b}}$ & $490.99^{\mathrm{a}}$ & $481.05^{\mathrm{a}}$ & $496.36^{\mathrm{a}}$ & $495.05^{\mathrm{a}}$ & 12.35 \\
3rd week & $527.56^{\mathrm{ab}}$ & $536.91^{\mathrm{a}}$ & $462.25^{\mathrm{c}}$ & $498.50^{\mathrm{b}}$ & $439.13^{\mathrm{c}}$ & 20.72 \\
4th week & $740.08^{\mathrm{b}}$ & $803.75^{\mathrm{ab}}$ & $783.43^{\mathrm{ab}}$ & $837.69^{\mathrm{a}}$ & $810.28^{\mathrm{ab}}$ & 45.68 \\
5th week & $739.91^{\mathrm{b}}$ & $797.85^{\mathrm{ab}}$ & $835.26^{\mathrm{a}}$ & $779.01^{\mathrm{ab}}$ & $759.27^{\mathrm{b}}$ & 40.09 \\
Total (0-5 week) & $2697.92^{\mathrm{c}}$ & $2863.6^{\mathrm{a}}$ & $2795.89^{\mathrm{ab}}$ & $2844.28^{\mathrm{a}}$ & $2735.66^{\mathrm{bc}}$ & 48.38 \\
Feed conversion ratio (feed/gain) & & & & & \\
1st week & 1.69 & 1.65 & 1.63 & 1.64 & 1.66 & 0.05 \\
2nd week & 1.76 & 1.74 & 1.75 & 1.74 & 1.7 & 0.10 \\
3rd week & 1.68 & 1.62 & 1.69 & 1.64 & 1.67 & 0.11 \\
4th week & $1.84^{\mathrm{a}}$ & $1.74^{\mathrm{c}}$ & $1.75^{\mathrm{bc}}$ & $1.76^{\mathrm{bc}}$ & $1.77^{\mathrm{b}}$ & 0.02 \\
5th week & $1.72^{\mathrm{a}}$ & $1.62^{\mathrm{d}}$ & $1.67^{\mathrm{b}}$ & $1.63^{\mathrm{cd}}$ & $1.66^{\mathrm{bc}}$ & 0.02 \\
Total (0-5 week) & $1.75^{\mathrm{a}}$ & $1.67^{\mathrm{c}}$ & $1.70^{\mathrm{b}}$ & $1.69^{\mathrm{bc}}$ & $1.70^{\mathrm{b}}$ & 0.01 \\
\hline
\end{tabular}

a-eValues with different superscripts in the same row differ significantly $(P<0.05)$. PSE $=$ Pooled standard error. Control $=$ Without organic acids; $A W-C=$ Activate continuous administration; $A W-P=$ Activate periodic administration; $N-C=$ Nutrilac continuous administration; N-P = Nutrilac periodic administration

The nutritional effects of Activateare due to its abundance of methionine, which is known to promote detoxification and stimulation of the hepatic system. Activate further plays an important role in the destruction of harmful microorganisms that affect animal performance and food safety. In a study on pigs, a dry organic acid blend of Activate was found to enhance the growth performance of weaning pigs as well as modulate the intestinal microbial population and $\mathrm{pH}$ level of early-weaned pigs (Li et al., 2008). In another study by Cole et al. (1968), supplementation of organic acids to drinking water not only was shown to improve growth performance but also reduce the number of $E$. coli in the gut of post-weaning pigs. Partnanen and Morz (1999) and Piva et al. (2002) reported that inclusion of organic acids in the diet could enhance growth performance and modulate intestinal microbiota in pigs. Dibner and Butin(2002) suggested that organic acids improve protein and energy digestibility by reducing microbial competition with the host for nutrients, decreasing endogenous nitrogen loss, lowering the incidence of sub-clinical infections and secretion of immune mediators, and reducing production of ammonia and other growthdepressing microbial metabolites. Any of these could be mechanisms through which butyrate improves feed utilization, leading to better performance of broilers. In this study, supplementation of organic acids increased carcass, breast, thigh and drumstick meat yields. The result coincides with the findings of Aksu et al. (2007), who reported that carcass, thigh, and breast weights of broiler scan be improved by organic acid supplementation at $4 \mathrm{~g} / \mathrm{kg}$ of feed. In a study by Atapattu and Nelligaswatta (2005), addition of citric acid to a rice byproduct-based diet was shown to linearly increase carcass weight of broilers. Further, dietary supplementation of $0.5 \%$ citric acid and $0.5 \%$ acetic acid has been found to linearly improve dressing yield by $3.31 \%$ over control (Islam et al., 2008). In addition, Chowdhury et al. (2009) and Denli et al. (2003) observed higher carcass weight in broilers receiving organic acids with antibiotics. However, previous studies have shown that carcass, breast and thigh yields are not affected by dietary butyric acid (Mahdavi and 
Hossain and Nargis (2016) Bang. J. Anim. Sci. 45 (1): 7-18

Table 3. Effects of organic acids on dressing parameters and internal organ weights of broilers (\% related to body weight)

\begin{tabular}{lcccccc}
\hline \multirow{2}{*}{ Items } & \multicolumn{3}{c}{ Treatment } & N & \multirow{2}{*}{ PSE } \\
\cline { 2 - 5 } & Control & AW-C & AW-P & N-C & N-P & \\
\hline Carcass yield & $58.94^{\mathrm{b}}$ & $64.41^{\mathrm{a}}$ & $63.20^{\mathrm{a}}$ & $63.06^{\mathrm{a}}$ & $62.24^{\mathrm{a}}$ & 1.13 \\
Head & $2.18^{\mathrm{d}}$ & $2.46^{\mathrm{a}}$ & $2.34^{\mathrm{c}}$ & $2.40^{\mathrm{b}}$ & $2.40^{\mathrm{b}}$ & 0.03 \\
Neck & $1.52^{\mathrm{c}}$ & $1.75^{\mathrm{a}}$ & $1.70^{\mathrm{b}}$ & $1.69^{\mathrm{b}}$ & $1.72^{\mathrm{b}}$ & 0.02 \\
Blood & 3.39 & 3.50 & 3.66 & 3.70 & 3.84 & 0.58 \\
Feather & 6.92 & 6.90 & 7.06 & 7.40 & 7.28 & 0.69 \\
Skin & 8.25 & 9.36 & 8.02 & 8.74 & 9.03 & 0.78 \\
Liver & 2.06 & 2.02 & 2.01 & 1.95 & 2.12 & 0.18 \\
Heart & 0.43 & 0.44 & 0.48 & 0.48 & 0.44 & 0.05 \\
Gizzard & $1.41^{\mathrm{bc}}$ & $1.62^{\mathrm{ab}}$ & $1.36^{\mathrm{c}}$ & $1.66^{\mathrm{a}}$ & $1.40^{\mathrm{bc}}$ & 0.12 \\
Abdominal fat & $1.51^{\mathrm{a}}$ & $1.28^{\mathrm{bc}}$ & $1.31^{\mathrm{b}}$ & $1.24^{\mathrm{c}}$ & $1.28^{\mathrm{bc}}$ & 0.03 \\
\hline
\end{tabular}

a-d Values with different superscripts in the same row differ significantly $(P<0.05)$. PSE $=$ Pooled standard error. Control $=$ Without organic acids; $A W-C=$ Activate continuous administration; $A W-P=$ Activate periodic administration; N-C = Nutrilac continuous administration; $\mathrm{N}-\mathrm{P}=$ Nutrilac periodic administration.

Torki, 2009), citric acid (Haque et al., 2010), formic acid (García et al., 2007) and propionic acid (Khosravi et al., 2012) supplementation. Similar to our study, Brzóska and Stecka, (2007) reported that inclusion of fumaric acid with probiotics and prebiotics in water increases dressing percentage compared to addition with feed or antibiotics. In a comparison of bacitracin methylene disalicylate or $0.1 / 0.2 \%$ butyric acid, Leeson et al. (2005) noted increased carcass weight and breast meat yield in birds fed $0.2 \%$ butyric acid. In a recent study, Saki et al. (2012) reported an increase in breast and thigh meat yields at 21 days, whereas the effect could not be observed at 42 days. Increased dressing yield upon organic acid supplementation could be attributed to higher live weight. This result is partially supported by Sapra and Mehta (1990), who observed increased edible meat yield at a higher body weight. The positive effect of organic acid supplementation on digestion is related to the slower passage of feed in the intestinal tract, better absorption of necessary nutrients, and less wet droppings (Van Der Sluis, 2002). Another explanation is that organic acids improve gastric proteolysis as well as the digestibility of proteins and amino acids (Samanta et al., 2010), thereby increasing the musculature of broilers.

In our study, organic acid supplementation increased head, neck, and gizzard relative weights. In agreement with our result, Aksu et al. (2007) has noted that neck and internal edible organ weights can be improved by organic acid supplementation at $4 \mathrm{~g} / \mathrm{kg}$ of feed. However,
Islam et al. (2008) found no differences in head, skin, giblet, and visceral relative weights in broilers fed acetic acid or citric acid. Saki et al. (2012) observed higher relative liver and heart weights as well as lower gizzard weight at 21 days, whereas the effect was not seen at 42 days. In this study, reduction of abdominal fat content was observed in the organic acid groups. This result is generally in line with those of Panda et al. (2009), who reported that abdominal fat content can be significantly reduced by butyric acid treatment compared to control or antibiotic treatment, and Lessard et al. (1993), who observed that pyruvic acid or citric acid supplementation reduces abdominal fat content.

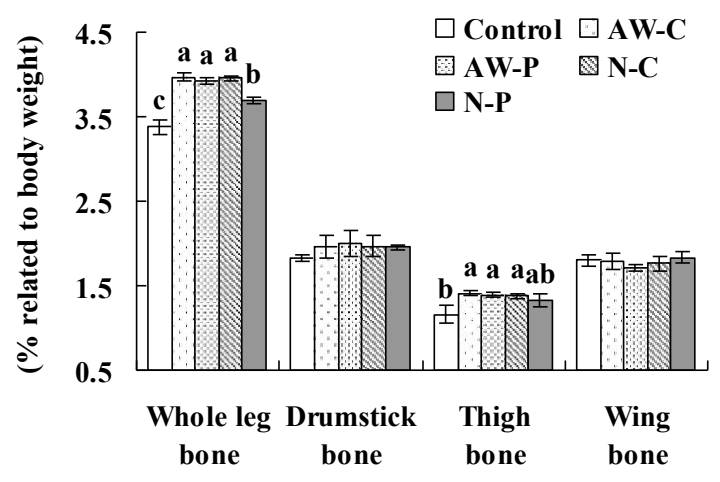

Figure 3. Effects of organic acids on bone development of broilers (\% related to body weight). Data are presented as the mean \pm SE. Bars within individual bones not sharing a common letter are significantly different $(P<0.05)$. Control = Without organic acids; $\mathrm{AW}-\mathrm{C}=$ Activate continuous administration; AW-P = Activate periodic administration; $\mathrm{N}-\mathrm{C}=$ Nutrilac continuous administration; $\mathrm{N}-\mathrm{P}=$ Nutrilac periodic administration 
Hossain and Nargis (2016) Bang. J. Anim. Sci. 45 (1): 7-18

Table 4. Effects of organic acids on bone length $(\mathrm{cm})$ of broilers

\begin{tabular}{lcccccc}
\hline \multirow{2}{*}{ Item } & \multicolumn{3}{c}{ Treatment } & PSE \\
\cline { 2 - 6 } & Control & AW-C & AW-P & N-C & N-P & \\
\hline Neck & 7.75 & 8.20 & 8.25 & 8.25 & 7.75 & 0.61 \\
Shank & $7.25^{\mathrm{b}}$ & $8.25^{\mathrm{a}}$ & $8.01^{\mathrm{a}}$ & $8.25^{\mathrm{a}}$ & $7.75^{\mathrm{a}}$ & 0.39 \\
Drumstick & $8.50^{\mathrm{c}}$ & $9.75^{\mathrm{a}}$ & $9.25^{\mathrm{b}}$ & $9.03^{\mathrm{b}}$ & $9.01^{\mathrm{b}}$ & 0.23 \\
Thigh & 6.25 & 6.40 & 6.50 & 6.50 & 6.10 & 0.47 \\
Wing & 11.00 & 11.50 & 11.75 & 11.00 & 11.25 & 0.69 \\
\hline
\end{tabular}

a-c Values with different superscripts in the same row differ significantly $(P<0.05)$. PSE $=$ Pooled standard error. Control = Without organic acids; $\mathrm{AW}-\mathrm{C}=$ Activate continuous administration; $\mathrm{AW}-\mathrm{P}=$ Activate periodic administration; $\mathrm{N}-\mathrm{C}=$ Nutrilac continuous administration; N-P $=$ Nutrilac periodic administration

Likewise, Ibrahim et al. (1997) has shown that organic acid supplementation reduces visible fat $(14.2 \%)$ and skin fat (36.9 and $40.2 \%$ of high and low energy controls, respectively) percentages in ducks. However, Brzóska and Stecka, (2007) reported that inclusion of fumaric acid with probiotics and prebiotics in water has no effect on gizzard, liver, or abdominal fat pad weight of broilers. In a report by Denli et al. (2003), dietary supplementation of organic acids was shown to have no effect on abdominal fat pad or liver weight compared with control. Similar results have been observed upon dietary supplementation of fumaric acid (Skinner et al.1991) and butyric acid (Mahdavi and Torki, 2009).These results indicate that the organic acids used in this study had significant effects on fat metabolism.

Organic acids have been evaluated numerous times for their efficacy in improving growth performance. However, there has been very little work investigating the efficacy of citric acid in mineral utilization by broiler chicks. In this study, organic acids appeared to increase whole leg and thigh bone relative weights, as well as shank and drumstick lengths. These results are in agreement with a study by Liem et al. (2008), who reported that the addition of citric acid, malic acid, and fumaric acid increases the percentage of tibia ash. Several organic acids have been reported to improve mineral absorption and phytate-P utilization when supplemented ton onruminant diets (Boling et al., 2000). Citric acid treatment has been shown to significantly increase the tibia ash content, thereby improving utilization of phosphorus (Chowdhury et al., 2009; Haque et al., 2010).

Similarly, use of citric acid found to increase retention of phosphorus (Brenes et al., 2003), tibia ash (Rafacz-Livingston et al., 2005; Martinez-Amezcua et al., 2006; Moghadam et al.2006), and toe ash (Atapattu and Nelligaswatta, 2005) in broiler chicks. In a recent study, Świątkiewicz and Arczewska-Wlosek (2012) reported that organic acids have no effects on tibial parameters; however, short chain fatty acids (SCFA; formic acid, propionic acid, and acetic acid)alone or in combination with medium chain fatty acids (caproic acid and capric acid) have been shown to increase the yielding load and stiffness of femurs. In another study, dietary supplementation of SCFA was found to significantly increase relative retention of calcium (45.0 vs. $41.1 \%)$.

It was concluded that SCFA can improve bone quality and calcium balance in broiler chickens fed either a diet with standard levels of calcium and phosphorus or a diet with reduced levels of these macro minerals. Deepa et al. (2011) noted previously that supplementation of citric acid, both individually and in combination with phytase, can significantly improve phosphorus retention in broilers. In detail, calcium and nitrogen retention were significantly higher in broiler groups that received phytase plus citric acid. Organic acids such as citric acid improve phosphorus and calcium retention by combining with dietary calcium, which reduces the formation of highly indigestible calcium phytate complexes. Moreover, low intestinal $\mathrm{pH}$ (created by organic acids) increases the solubility and absorption of phosphorus and calcium in the small intestine (Overland et al., 2002), thereby improving retention of phosphorus and calcium.

\section{Conclusion}

Supplementation of organic acids to water improved growth performance, meat yield, 
dressing parameters and bone development of broiler in this study. Results also indicated that continuous addition exerted beneficial effects compared to periodic addition. Further, Activate showed better results compared to nutrilac in terms of some tested parameters. It is also suggested, due to the natural buffering capacity of water and interactions with minerals, that producer monitor the $\mathrm{pH}$ level of drinking water when using acidifiers at the manufacturer's recommended levels.

\section{References}

Abdel-Fattah SA, EI-Sanhoury, MH, EI-Mednay NM, Abdul-Azeem F (2008). Thyroid activity of broiler chicks fed supplemental organic acids. International Journal of Poultry Science. 7:215-222.

Afsharmanesh M, Pourreza J (2005). Effect of calcium, citric acid, ascorbic acid, vitamin D3 on the efficacy of microbial phytase in broiler starters fed wheat-based diets on performance, bone mineralization and ileal digestibility. International Journal of Poultry Science. 4:418-424.

Akbari MR, Kermanshahi H, Kalidari GA (2004). Effect of acetic acid administration in drinking water on performance and growth characteristics and ileal microflora of broiler chickens. Journal of Science and Technology of Agriculture and Natural Resources. 8:139-148.

Aksu T, Ates CT, Erdogan Z, Baytok E (2007). The response of broilers to dietary organic acid mixture. Indian Veterinary Journal. 84: 385387.

Al-Tarazi YH, Alshawabkeh K (2003). Effect of dietary formic and propionic acids on Salmonella pullorum shedding and mortality in layer chicks after experimental infection. Journal of veterinary medicine. B, Infectious diseases and veterinary public health. 50: 112-117.

Atapattu NSBM, Nelligaswatta CJ (2005). Effects of citric acid on the performance and utilization of phosphorous and crude protein in broiler chickens fed rice byproducts based diets. International Journal of Poultry Science. 4:990-993.

Boling SD, Webel, DM, Mavromichalis I, Parsons CM, Baker DH (2000). The effects of citric acid on phytate phosphorus utilization in young chicks and pigs. Journal of Animal Science. 78: 682-689.

Brenes A, Viveros A, Arija I, Centeno C, Pizarro M, Bravo C (2003). The effect of citric acid and microbial phytase on mineral utilization in broiler chicks. Anim. Feed Sci. Technol. 110: 201-219.

Brzoska F, Steck K (2007). Effect of probiotic, prebiotic and acidifier on body weight of broiler chickens, feed conversion and carcass meat composition. Annals of Animal Science. 7: 279-288.

Byrd JA, Anderson RC, Brewer RL, Callaway TR, Bischoff KM, McReynolds JL, Caldwell DJ, Hargis BM, Herron KL, Bailey RH (2001). Effect of lactic acid administration in the drinking water during pre slaughter feed withdrawal on Salmonella and Campylobacter contamination of broilers. Poultry Science. 80(3): 278-283.

Canibe N, Engberg RM, Jensen BB (2001). An overview of the effects of organic acids on gut flora and gut health. Workshop on Alternatives to Feed Antibiotics and Anticoccidials in the Pig and Poultry Meat Production. October 13-16, Oslo, Norway. Available at: wwwskara.slu.se/Workshop\%20Norge/organic_acid s_canibe_et_al.pdf.

Chaveerach P, Keuzenkamp DA, Lipman LJA, Van Knapen $F$ (2004). Effect of organic acids in drinking water for young broilers on Campylobacter infection, volatile fatty acid production, gut microflora and histological cell changes. Poultry Science. 83: 330-334.

Chowdhury R, Islam KMS, Khan MJ, Karim MR, Haque MN, Khatun M, Pesti GM (2009). Effect of citric acid, avilamycin, and their combination on the performance, tibia ash, and immune status of broilers. Poultry Science. 88: 1616-1622.

Cole DJA, Beal RM, Luscombe JR (1968). The effect on performance and bacterial flora of lactic acid, propionic acid, calcium propionate and calcium acrylate in the drinking water of weaned pigs. Veterinary Record. 83: 459-464.

Cox NA, McHan F, Bailey JS (1994). Effect of butyric or lactic acid on the in vitro colonization of Salmonella typhimurium. Journal of Applied Poultry Research. 3: 315318.

Deepa C, Jeyanthi GP, Chandrasekaran D (2011). Effect of phytase and citric acid 


\section{Performances of broilers with organic acid supplementation}

supplementation on the growth performance, phosphorus, calcium and nitrogen retention on broiler chicks fed with low level of available phosphorus. Asian Journal of Poultry Science. 5:28-34.

Denli M, Okan F, Celik K (2003). Effect of dietary probiotic, organic acid and antibiotic supplementation to diets on broiler performance and carcass yield. Pakistan Journal of Nutrition. 2: 89-91.

Desai DN, Patwardhan DS, Ranade AS (2007). Acidifiers in poultry diets and poultry production. In: Acidifiers in Animal Nutrition-A Guide for Feed Preservation and Acidification to Promote Animal Performance (Ed. C. Lückstädt). Nottingham University Press. pp. 63-69.

Dibner JJ, Buttin RJ (2002). Use of organic acids as a model to study the impact of gut microflora in nutrition and metabolism. Journal of Applied Poultry Research. 11: 453-463.

Freitag M (2007). Organic acids and salts promote performance and health in animal husbandry. In: Acidifiers in Animal Nutrition-A Guide for Feed Preservation and Acidification to Promote Animal Performance (Ed. C. Lückstädt). Nottingham University Press. pp.1-11.

Galfi P, Bokori J (1990). Feeding trial in pigs with a diet containing sodium n-butyrate. Acta Veterinaria Hungarica. 38: 3-17.

García V, Catalá-Gregori P, Hernández F, Megías MD, Madrid J (2007). Effect of formic acid and plant extracts on growth, nutrient digestibility, intestine mucosa morphology, and meat yield of broilers. Journal of Applied Poultry Research. 16: 555-562.

Gibbens JC, Pascoe SJ, Evans SJ, Davies RH, Sayers AR (2001). A trial of biosecurity as a means to control Campylobacter infection of broiler chickens. Preventive Veterinary Medicine. 48: 85-99.

Giesen, A (2005). The value of organic acids in drinking water. World Poultry. 21: 15-17.

Gunal M, Yayli G, Kaya O, Karahan N, Sulak O (2006). The effects of antibiotic growth promoter, probiotic or organic acid supplementation on performance, intestinal microflora and tissue of broilers. International Journal of Poultry Science. 5: 149-155.
Haque MN, Islam KMS, Akbar MA, Chowdhury R, Khatun M, Karim MR, Kemppainen BW (2010). Effect of dietary citric acid, flavomycin and their combination on the performance, tibia ash and immune status of broiler. Canadian Journal of Animal Science. 90: 57-63.

Harada E, Hiroko K, Kobayashi E, Tsuchita H (1988). Postnatal development of biliary and pancreatic exocrine secretion in piglets. Comparative Biochemistry and Physiology. 91A: 43-51.

Ibrahim KA, Osman MM, Saleh ES (1997). Effect of gemfibrozil and citric acid as lipid regulating agents on duck performance. Egyptian Poultry Science Journal. 17: 77-92.

Islam MZ, Khandaker ZH, Chowdhury SD, Islam KMS (2008). Effect of citric acid and acetic acid on the performance of broilers. Journal of Bangladesh Agricultural University. 6: 315320.

Izat $A L$, Adams MH, Cabel MC, Colberg M, Reiber MA, Skinner JT, Waldroup PW (1990). Effects of formic acid or calcium format in feed on performance and microbiological characteristics of broiler. Poultry Science. 69: 1876-1882.

Jones R (1984). A standard method of dissection of poultry for carcass analysis. A Technical Note No. 222. West of Scotland Agricultural College, Auchincruive Ayr, KA6 5HW, Scotland.

Kapperud G, Skjerve E, Vik L, Hauge K, Lysaker A, Aalmen I, Ostroff SM, Potter M (1993). Epidemiological investigation of risk factors for campylobacter colonization in Norwegian broiler flocks. Epidemiology Infection. 111: 245-255.

Khosravi A, Boldaji F, Dastar B, Hasani S (2012). Comparison of broiler performance and carcass parameters when fed diets containing a probiotic, an organic acid or antibiotic growth promoter. Asian Journal of Animal and Veterinary Advances. 7: 318-325.

Khosravi A, Boldaji F, Dastar B, Hasani S (2012). Comparison of broiler performance and carcass parameters when fed diets containing a probiotic, an organic acid or antibiotic growth promoter. Asian Journal of Animal and Veterinary Advances. 7: 318-325.

Leeson S, Namkung H, Antongiovanni M, Lee EH (2005). Effect of butyric acid on the 
performance and carcass yield of broiler chickens. Poultry Science. 84: 1418-1422.

Lessard P, Lefrançois MR, Bernier JF (1993). Dietary addition of cellular metabolic intermediates and carcass fat deposition in broilers. Poultry Science. 72: 535-45.

Li Z, Yi G, Yin J, Sun P, Li D, Knight C (2008). Effects of organic acids on growth performance, gastrointestinal ph, intestinal microbial populations and immune responses of weaned pigs. Asian-Australasian Journal of Animal Science. 21: 252-261.

Liem A, Pesti GM, Edwards Jr. HM (2008). The effect of several organic acids on phytase phosphorus hydrolysis in broiler chicks. Poultry Science. 87: 689-693.

Mahdavi R, Torki M (2009). Study on usage period of dietary protected butyric acid on performance, carcass characteristics, serum metabolite levels and humoral immune response of broiler chickens. Journal of Animal and Veterinary Advances. 8: 1702-1709.

Martinez-Amezcua C, Parsons CM, Baker DH (2006). Effect of microbial phytase and citric acid on phosphorus bioavailability, apparent metabolizable energy, and amino acid digestibility in distillers dried grains with soluble in chicks. Poultry Science. 85: 470475.

Moghadam AN, Pourreza J, Samie AH (2006). Effect of different levels of citric acid on calcium and phosphorus efficiencies in broiler chicks. Pakistan Journal of Biological Science. 9: 1250-1256.

NRC. 1994. Nutrient Requirements of Poultry. 9th rev. edn. National Academy Press, Washington, DC.

Overland M, Kjeldsen K, Granli T (2002). Acid salts improve enzyme efficiency. Feed Mix. 10:10-12.

Ozduven ML, Samli HE, AA Okur FK, Akyurek H, Senkoylu N (2009). Effects of mannanoligosaccharide and/or organic acid mixture on performance, blood parameters and intestinal microbiota of broiler chicks, Italian Journal of Animal Science. 8: 595-602.

Panda AK, Rao SVR, Raju MVLN, Sunder GS (2009). Effect of butyric acid on performance, gastrointestinal tract health and carcass characteristics in broiler chickens. Asian-
Australasian Journal of Animal Science. 22: 1026-1035.

Partanen KH, Morz Z (1999). Organic acids for performance enhancement in pig diets. Nutrition Research Reviews. 12: 117-145.

Pearson AD, Greenwood M, Healing TD, Rollins D, Shahamat M, Donaldson J, Colwell RR (1993). Colonization of broiler chickens by waterborne Campylobacter jejuni. Applied Environmental Microbiology. 59: 987-996.

Philipsen IPLJ (2006). Acidifying drinking water supports performance. World Poultry. 22: 2021.

Piva A, Casadei G, Biagi G (2002). An organic acid blend can moderate swine intestinal fermentaion and reduce microbial proteolysis. Canadian Journal of Animal Science. 82: 527537.

Rafacz-Livingston KA, Martinez-Amezcua C, Parsons CM, Baker DH, Snow J (2005). Citric acid improves phytate phosphorus utilization in crossbred and commercial broiler chicks. Poultry Science. 84: 1370-1375.

Rahmani HR, Speer W (2005). Natural additives influence the performance and humoral immunity of broilers. International Journal of Poultry Science. 4: 713-717.

Ravindran V, Kornegay ET (1993). Acidification of weaner pig diets: A review. Journal of Science Food and Agriculture. 62: 313-322.

Runho RC, Sakomura NK, Kuana S, Banzatto D, Junqueira OM, Stringhini JH (1997). Use of an organic acid (fumaric acid) in broiler rations. Revista Brasileira de Zootecnia. 26: 11831191.

Saki AA, Harcini RN, Rahmatnejad E, Salary J (2012). Herbal additives and organic acids as antibiotic alternatives in broiler chickens diet for organic production. African Journal of Biotechnology. 11: 2139-2145.

Samanta S, Haldar S, Ghosh TK (2010). Comparative efficacy of an organic acid blend and bacitracin methylene disalicylate as growth promoters in broiler chickens: effects on performance, gut histology and small intestinal milieu. Veterinary Medicine International. 8 pages, Article ID 645150.

Sapra KI, Mehta RK (1990). A comparative study on addition Livol (Herbal growth promoter) and some chemical growth promoters in the 


\section{Performances of broilers with organic acid supplementation}

diet of broiler chicks. Indian Journal of Animal Production Management. 6: 115-118.

SAS. 2003. SAS User's Guide. Version 9.1 ed. SAS Inst. Inc., Cary, NC, USA.

Skinner JT, Izat AL, Waldroup PW (1991). Research note: Fumaric acid enhances performance of broiler chickens. Poultry Science. 70:1444-1447.

Stonerock R (2007). Possibilities of Salmonella control with the aid of acidifiers. In: Acidifiers in Animal Nutrition-A Guide for Feed Preservation and Acidification to Promote Animal Performance (Ed. C. Lückstädt). Nottingham University Press. pp. 21-29.

Sureshkumar R (2011). Drinking Water Acidification in Poultry: A Novel Approach. Available at: http://www.poulvet.com/poultry/articles/water acidification.php.

Świątkiewicz S, Arczewska-Wlosek A (2012). Bone quality characteristics and performance in broiler chickens fed diets supplemented with organic acids. Czech Journal of Animal Science. 57: 193-205.
Thaela MJ, Jensen MS, Pierzynowski SG, Jakob S, Jensen BB (1998). Effect of lactic acid supplementation in pigs after weaning. Journal of Animal Feed Science. 7: 181-183.

Van Der Sluis W (2002). Water quality is important but often overestimated. World Poultry. 18: 26-31.

Walsh MC, Sholly DM, Hinson RB, Saddoris $K L$, Sutton AC, Radcliff JS, Odgaard R, Murphy J, Richert BT (2007). Effects of water and diet acidification with and without antibiotics on weanling pig growth and microbial shedding. Journal of Animal Science. 85: 1799-1809.

Yang Y, Iji PA, Choct M (2009). Dietary modulation of gut microflora in broiler chickens: a review of the role of six kinds of alternatives to in-feed antibiotics. World's Poulty Science Journal. 65: 97-114.

Yi GF, Atwell CA, Hume JA, Dibner J], Knight CD, Richards JD (2007). Determining the methionine activity of mintrex organic trace minerals in broiler chicks by using radiolabel tracing or growth assay. Poultry Science. 86: 877-887. 